Maurer School of Law: Indiana University

Winter 2014

\title{
Evolving Values, Animus, and Same-Sex Marriage
}

Daniel O. Conkle

Indiana University Maurer School of Law, conkle@indiana.edu

Follow this and additional works at: https://www.repository.law.indiana.edu/ilj

Part of the Constitutional Law Commons, Courts Commons, Family Law Commons, Fourteenth Amendment Commons, and the Sexuality and the Law Commons

\section{Recommended Citation}

Conkle, Daniel O. (2014) "Evolving Values, Animus, and Same-Sex Marriage," Indiana Law Journal: Vol. 89 : Iss. 1 , Article 3.

Available at: https://www.repository.law.indiana.edu/ilj/vol89/iss1/3

This Essay is brought to you for free and open access by the Law School Journals at Digital Repository @ Maurer Law. It has been accepted for inclusion in Indiana Law Journal by an authorized editor of Digital Repository @ Maurer Law. For more information, please contact rvaughan@indiana.edu.

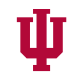

JEROME HALL LAW LIBRARY INDIANA UNIVERSITY Maurer School of Law
Bloomingtoan 


\title{
Evolving Values, Animus, and Same-Sex Marriage
}

\author{
Daniel O. Conkle*
}

During oral argument in Hollingsworth v. Perry, ${ }^{1}$ Justice Scalia pressed advocate Theodore Olson with a provocative question: "I'm curious, . . . when did it become unconstitutional to exclude homosexual couples from marriage? 1791? 1868, when the Fourteenth Amendment was adopted? . . . [S] ome time after Baker [v. Nelson, ${ }^{2}$ decided in 1972], where we said it didn't even raise a substantial Federal question? When-when-when did the law become this?"3 In the wake of the Supreme Court's decisions in Hollingsworth and in United States v. Windsor, ${ }^{4}$ of course, the premise of Scalia's question does not yet hold. The Court evaded the Fourteenth Amendment issue in Hollingsworth, ${ }^{5}$ and it explicitly confined its decision in Windsor to the federal Defense of Marriage Act (DOMA). ${ }^{6}$ Baker $v$. Nelson may still be controlling. In any event, the Supreme Court has not recognized a constitutional right to same-sex marriage. Not yet. But such a ruling seems increasingly inevitable. And if and when the Court rules in that manner, Scalia's question will return to center stage. ${ }^{7}$

There are various possible groundings for a constitutional right to same-sex marriage. Creative minds might contend that the Fourteenth Amendment, properly understood, has always protected such a right. If so, then the answer to Scalia's question is 1868 , when the Amendment was ratified. It simply took us a while-a century and a half! - to understand the Amendment's implications. Indeed, Professor Jack M. Balkin, among others, might be inclined to accept this sort of "originalist" argument. ${ }^{8}$ But it requires an account of original meaning that is so

$\uparrow$ Copyright (C) 2014 Daniel O. Conkle.

* Robert H. McKinney Professor of Law, Nelson Poynter Scholar, and Adjunct Professor of Religious Studies, Indiana University Bloomington. Thanks to the Indiana Law Journal for organizing this symposium and to my colleagues Dawn Johnsen, Steve Sanders, Ryan Scott, Deborah Widiss, and Elisabeth Zoller for their comments and suggestions.

1. 133 S. Ct. 2652 (2013).

2. 409 U.S. 810 (1972) (mem.).

3. Transcript of Oral Argument at 38, Hollingsworth v. Perry, 133 S. Ct. 2652 (2013) (No. 12-144) (quoting Justice Scalia).

4. 133 S. Ct. 2675 (2013).

5. In a five-to-four ruling, the Court concluded that the Ninth Circuit lacked jurisdiction and that its judgment invalidating California's ban on same-sex marriage should be vacated. Hollingsworth, $133 \mathrm{~S}$. Ct. at 2668. Neither the majority nor the dissenters reached the merits of the Fourteenth Amendment issue.

6. Windsor, 133 S. Ct. at 2696.

7. In fact, a variant of Scalia's question, more broadly framed, has been debated for decades. See, e.g., Stephen R. Munzer \& James W. Nickel, Does the Constitution Mean What It Always Meant?, 77 CoLum. L. REV. 1029 (1977).

8. See Francis Wilkinson, Originalism, Scalia and Gay Marriage: An Interview with Jack Balkin, BloOMBerg (Mar. 26, 2013, 10:02 AM), http://www.bloomberg.com/news /2013-03-26/originalism-scalia-and-gay-marriage-an-interview-with-jack-balkin.html; $\quad c f$. Jack M. Balkin, Abortion and Original Meaning, 24 Const. Comment. 291 (2007) (contending that the original meaning of the Fourteenth Amendment can be understood to include the right to abortion). Balkin elaborates his theory in JACK M. BALKIN, LIVING 
abstract—or, as Balkin would have it, so "thin" — as to give originalism little or no constraining force, at least in the context of Fourteenth Amendment claims. In reality, the meaning of the Fourteenth Amendment has changed over time, and it will continue to do so. ${ }^{10}$ In my judgment, moreover, this is precisely as it should be. ${ }^{11}$

When the Supreme Court interprets the capacious language of the Due Process and Equal Protection Clauses, ${ }^{12}$ its task is art as much as science, judicial statesmanship as much as technical craft. The Court mediates past, present, and future, identifying individual rights that befit the evolving political morality of our society. By its very nature, the Fourteenth Amendment protects minority rights from state and local majoritarian oppression. But what rights, in particular, does the Amendment protect? In deciding this question, the Justices rely in part on precedent and in part on their own understandings of liberty and equality. At the same time, however, the Court generally acts, and properly so, in a manner that tracks the evolving values of the country as a whole. In so doing, the Court confronts contentious political-moral issues with a measure of judicial humility, and it deflects the charge that its actions are unduly countermajoritarian.

When asked to recognize a new constitutional right, the Court should act neither too soon nor too late. The Court errs if it trumps the political process and federalism prematurely, as it seemingly did in Roe v. Wade. ${ }^{13}$ Yet at some point a claim of right, if persuasive to the Court as a matter of justice, should no longer be denied as a matter of prudence. At some point the country will be ready, or at least ready enough, for the Court to recognize a national constitutional right. As Professor Alexander M. Bickel observed, "the Court should declare as law only

ORIGINALISM (2011)

9. See Jack M. Balkin, Must We Be Faithful to Original Meaning?, 7 Jerusalem ReV. Legal Stud. 57, 70-80 (2013).

10. Under Balkin's sophisticated account, originalism itself can incorporate this change, with originalism and living constitutionalism being seen as "two sides of the same coin." Id. at 80 .

11. In her thoughtful and thought-provoking contribution to this symposium, my colleague Dawn Johnsen likewise addresses the issue of constitutional change, offering observations that are in some respects complementary to my own. See Dawn Johnsen, Windsor, Shelby County, and the Demise of Originalism: A Personal Account, 89 IND. L.J. 3 (2014).

12. "No state shall ... deprive any person of life, liberty, or property, without due process of law; nor deny to any person within its jurisdiction the equal protection of the laws.” U.S. Const. amend. XIV, § 1 .

13. 410 U.S. 113 (1973). Justice Ginsburg, for example, has contended that Roe "short-circuited the development of a political groundswell that was building at the state and local level—not only on the issue of abortion—but on all phases of women's rights." Allen Pusey, Ginsburg: Court Should Have Avoided Broad-Based Decision in Roe v. Wade, ABA JOURNAL (May 13, 2013, 9:20 AM), http://www.abajournal.com/news/article/ginsburg _expands_on_her_disenchantment_with_roe_v._wade_legacy/; see also Ruth Bader Ginsburg, Some Thoughts on Autonomy and Equality in Relation to Roe v. Wade, 63 N.C. L. REV. 375, 379-82, 385 (1985) (arguing that the Court should have confined itself to a narrow decision in Roe and describing the Court's broad ruling as "[h]eavy-handed judicial intervention"). For a competing perspective, see Linda Greenhouse \& Reva B. Siegel, Before (and After) Roe v. Wade: New Questions About Backlash, 120 YALE L.J. 2028 (2011). 
such principles as will —in time, but in a rather immediate foreseeable future — gain general assent." ${ }^{, 14}$ And whenever the Court acts, it should proceed with a measure of humility and caution, recognizing legitimate competing interests and minimizing its intrusion on our system of democratic self-government.

Just as American societal values have changed over time, so too have the Supreme Court's interpretations of the Fourteenth Amendment. Thus, the Court has already expanded the Amendment far beyond what its framers and ratifiers had in mind. ${ }^{15}$ Should the Court expand the Amendment even further, to embrace a right to same-sex marriage? Society's perspective on this issue is in a state of flux. In a notable development in 2012, President Barack Obama, citing a new understanding of his Christian faith, announced that he no longer opposes same-sex marriage but instead supports it. ${ }^{16}$ And President Obama is not alone; the views of many Americans recently have "evolved" in the same direction. ${ }^{17}$ Indeed, as I will discuss, there has been a remarkably rapid, and seemingly inexorable, shift of opinion from opposition to approval. So, is it time for the Court to declare a national constitutional right? Or should the Court await further, more definitive evidence of a societal consensus that is likely to be enduring? And under what form of reasoning might a Fourteenth Amendment right be justified, either now or in the future?

These questions have no easy answers. Even so, I hope to shed some light on them, especially the last one. Accordingly, I will briefly explore and evaluate three possible lines of Supreme Court reasoning, each of which might support a Fourteenth Amendment right to same-sex marriage: first, substantive due process; second, heightened scrutiny equal protection; and third, rational basis equal protection coupled with a finding of illicit "animus." As we will see, each form of constitutional justification can find support in evolving national values. In my judgment, however, the first two alternatives, with primary emphasis on the second, present the best and strongest arguments for a right to same-sex marriage. By contrast, I think it would be misguided, or at least imprudent, for the Court to rely on the third line of reasoning.

14. Alexander M. Bickel, The Least Dangerous Branch: The Supreme Court at THE BAR of Politics 239 (Yale Univ. Press 1986) (1962). With the benefit of hindsight, it seems clear that Roe v. Wade did not satisfy this condition, because the Court's 1973 decision did not garner "general assent" in "a rather immediate foreseeable future." Indeed, it has yet to do so even now, some forty years later. Whether and how the Court's decision itself contributed to the ongoing controversy is a separate question. See supra note 13.

15. In the context of women's rights, for instance, the Court has discarded Fourteenth Amendment doctrine dating back to the $1870 \mathrm{~s}$ - and presumably reflecting the framers' and ratifiers' sentiments - as "no longer consistent with our understanding of the family, the individual, or the Constitution." Planned Parenthood of Se. Pa. v. Casey, 505 U.S. 833, 897 (1992).

16. Jackie Calmes \& Peter Baker, Obama Endorses Same-Sex Marriage, Taking Stand on Charged Social Issue, N.Y. TimES, May 10, 2012, at A1.

17. Prior to his announcement, President Obama had stated that his views on the issue were "evolving." Id. 


\section{Substantive Due Process}

The substantive due process argument for same-sex marriage builds upon a line of cases beginning with the Supreme Court's 1965 decision in Griswold v. Connecticut..$^{18}$ In these cases, relying mainly on the Due Process Clause, the Court has recognized a number of unenumerated constitutional rights, including the right to conventional marriage ${ }^{19}$ and the right of adults, including homosexuals, to engage in consensual sexual conduct. ${ }^{20}$ At times the Court has asserted that substantive due process rights are confined to rights that "are, objectively, 'deeply rooted in this Nation's history and tradition", ${ }^{\prime 21}$ - that is, rights that have broad and longstanding historical support, as revealed in specific legal policies and social practices. ${ }^{22}$ This backward-looking theory of historical tradition might well support the protection of conventional marriage, ${ }^{23}$ but it plainly would not support a right to same-sex marriage. ${ }^{24}$ Hardly a deeply rooted American tradition, same-sex

18. 381 U.S. 479 (1965). In fact, this line of cases, more broadly understood, can be seen to include earlier decisions as well. See, e.g., Skinner v. Oklahoma, 316 U.S. 535 (1942); Pierce v. Soc'y of Sisters, 268 U.S. 510 (1925); Meyer v. Nebraska, 262 U.S. 390 (1923).

19. Zablocki v. Redhail, 434 U.S. 374, 384 (1978) (declaring that "the right to marry is part of the fundamental 'right of privacy' implicit in the Fourteenth Amendment's Due Process Clause").

20. Lawrence v. Texas, 539 U.S. 558 (2003).

21. Washington v. Glucksberg, 521 U.S. 702, 720-21 (1997) (quoting Moore v. City of East Cleveland, 431 U.S. 494, 503 (1977) (plurality opinion)); cf. id. (quoting the more abstract "ordered liberty" formulation of Palko v. Connecticut, 302 U.S. 319, 325, 326 (1937), but using this language in a restrictive manner, noting that substantive due process rights must be deeply rooted historically "and 'implicit in the concept of ordered liberty,' such that "neither liberty nor justice would exist if they were sacrificed"' (emphasis added)).

22. See id. at 710-28.

23. But cf. Nelson Tebbe \& Deborah A. Widiss, Equal Access and the Right to Marry, 158 U. PA. L. REV. 1375, 1401-07 (2010) (suggesting that substantive due process might not protect a right to civil marriage, not even conventional marriage, in the sense that the government, in theory, could abolish civil marriage altogether).

24. See United States v. Windsor, 133 S. Ct. 2675, 2714-15 (2013) (Alito, J., dissenting). One might resist this conclusion by contending that the tradition of marriage should be conceptualized more broadly, at a level of generality sufficient to encompass marriage between consenting adults, without regard to the conventional opposite-sex limitation. See Perry v. Schwarzenegger, 704 F. Supp. 2d 921, 991-93 (2010), aff'd on other grounds sub nom. Perry v. Brown, 671 F.3d 1052 (9th Cir. 2012), vacated and remanded sub nom. Hollingsworth v. Perry, 133 S. Ct. 2652 (2013); see also Tebbe \& Widiss, supra note 23, at 1391-95 (advancing this argument, but conceding that it has had very limited success in the courts); see generally Laurence H. Tribe \& Michael C. Dorf, Levels of Generality in the Definition of Rights, 57 U. CHI. L. REV. 1057, 1088 (1990) (noting that "historical traditions, like rights themselves, exist at various levels of generality"). As I have explained elsewhere, however, this move toward abstraction - defining traditions at levels of generality that historical actors plainly would have rejected - deprives the theory of historical tradition of its ability to provide an objective standard of judicial decision making. See Daniel O. Conkle, Three Theories of Substantive Due Process, 85 N.C. L. REV. 63, 92-94 (2006). At the same time, it undermines the theory's normative justification, a justification that depends 
marriage was not recognized by any state until 2003 (nor by any country until 2000)..$^{25}$

Conversely, at other times the Court has suggested a more progressive, forwardlooking theory of substantive due process, a theory of evolving national values. Under this decision-making model, the Court can recognize an unenumerated right despite the absence of historical support, as long as the right has broad support in the contemporary United States. Under this approach, constitutional rights can emerge over time, reflecting ongoing legal developments, especially at the statelaw level, which may suggest a salutary maturation of societal thinking. ${ }^{26}$ This type of progressive methodology played a prominent role in the Court's 2003 decision in Lawrence v. Texas, ${ }^{27}$ which protected the right of homosexual adults to engage in consensual sexual conduct. It likewise might support a right to same-sex marriage, although - in the absence of additional state-law changes in this settingthe argument would go considerably beyond the Court's reasoning in Lawrence. ${ }^{28}$

In Lawrence, the Court advanced various justifications for its decision, including the Justices' own determination that criminal prohibitions on homosexual conduct violate "liberty of the person," which "presumes an autonomy of self that includes freedom of thought, belief, expression, and certain intimate conduct." 29 The Justices did not dismiss the opposing view as bigotry or intolerance, observing that it may reflect "profound and deep convictions accepted as ethical and moral principles. ${ }^{, 30}$ Even so, they concluded that the claim of liberty was paramount and must prevail. ${ }^{31}$ Notably, however, the Justices emphasized that their own understanding of liberty was supported by a contemporary national consensus. Thus, the Court put aside the long history of sodomy prohibitions, both in America

in part on considerations of democratic self-government, in part on Burkean philosophy, and in part on society's interests in legal stability and in protecting settled expectations concerning individual freedom. See id. at 90-92, 94-96; Michael W. McConnell, The Right to Die and the Jurisprudence of Tradition, 1997 UTAH L. REV. 665, 682-85, 683 n.96. The move toward abstraction here, to my mind, is similar to the move toward abstraction in expansive understandings of originalism, and I find neither of these efforts particularly helpful in determining the scope of contemporary constitutional rights.

25. Massachusetts was the first state and Netherlands the first country. See Windsor, 133 S. Ct. at 2715 (Alito, J., dissenting).

26. In still other cases, especially in the context of abortion, the Court has gone even further, embracing a theory of reasoned judgment. Under this theory, the Court, through a process of political-moral reasoning, is free to recognize rights even if the rights lack widespread historical or contemporary support. The Court's various decisions thus reflect three competing theories of substantive due process: historical tradition, evolving national values, and reasoned judgment. In an earlier article, using criteria that draw upon considerations of majoritarian self-government, judicial objectivity, and functional utility, I have explored and evaluated these three theories, arguing that although each has strengths and weaknesses, the best approach, on balance, is that of evolving national values. See Conkle, supra note 24 .

27. 539 U.S. 558 (2003).

28. The following analysis of Lawrence draws upon Conkle, supra note 24, at 121-23.

29. 539 U.S. at 562.

30. Id. at 571 .

31. See id. at 574. To this extent, the Court's decision relied on a methodology of reasoned judgment. For elaboration, see Conkle, supra note 24, at 119-21. 
and in western civilization generally, concluding instead that "our laws and traditions in the past half century are of most relevance here." 32 These legal and societal changes, the Court argued, revealed "an emerging awareness that liberty gives substantial protection to adult persons in deciding how to conduct their private lives in matters pertaining to sex.",33

More specifically, the Court cited the Model Penal Code of 1955, which recommended the repeal of laws forbidding consensual sodomy, and the eventual legislative adoption of this approach by a substantial majority of the states. ${ }^{34}$ These legislative developments, coupled with five state court invalidations under state constitutional law, ${ }^{35}$ left only thirteen states with sodomy prohibitions at the time of Lawrence. ${ }^{36}$ Even in these thirteen states, moreover, consensual sodomy was rarely prosecuted, suggesting that legal and social disapproval was waning. ${ }^{37}$ The Court's decision in Lawrence, therefore, was supported by powerful evidence of a national consensus, a legal and societal consensus that had developed and endured over the course of several decades.

Is there a similar trend favoring the recognition of same-sex marriage? Yes, but this trend, to date, is far less compelling. Indeed, except in the last few years, state law making has been moving decidedly in the opposite direction, with some thirty states recently amending their state constitutions to expressly prohibit same-sex marriage. ${ }^{38}$ In the last five years, however, it seems that the tide has turned. Not counting California, which is implementing same-sex marriage under a federal court mandate ${ }^{39}$ fifteen states and the District of Columbia have acted to recognize same-sex marriage. ${ }^{40}$ Several of these jurisdictions have acted as the result of state court rulings under state constitutional law; the remainder have acted legislatively or by popular referendum. ${ }^{41}$ Notably, the largest part of this trend is extremely recent: Except for Massachusetts, all of the same-sex marriage jurisdictions have acted since 2008, with most of them acting only in 2012 or $2013 .{ }^{42}$ And even now,

32. Lawrence, 539 U.S. at 571-72.

33. Id. at 572 .

34. Id. (citing Model Penal Code $§ 213.2 \mathrm{cmt} .2$ (1980)).

35. See id. at 576.

36. Id. at 573. Looking beyond our nation's borders, the Court also cited comparable legislative and judicial action in Europe. Id. at 572-73, 576.

37. See id. at 573.

38. One state, North Carolina, adopted this sort of constitutional amendment as recently as 2012. See Campbell Robertson, Ban on Gay Marriage Passes in North Carolina, N.Y. TimeS, May 9, 2012, at A15. All of the other states acted between 1998 and 2008. For a chronological listing of these state constitutional amendments, see History of State Constitutional Marriage Bans, HuM. RTs. CAMPAIGN, http://www.hrc.org/resources/entry /state-constitutional-marriage-bans\#_ftn1.

39. See Perry v. Schwarzenegger, 704 F. Supp. 2d 921 (2010), aff'd on other grounds sub nom. Perry v. Brown, 671 F.3d 1052 (9th Cir. 2012), vacated and remanded sub nom. Hollingsworth v. Perry, 133 S. Ct. 2652 (2013).

40. Defining Marriage: State Defense of Marriage Laws and Same-Sex Marriage, NAT'L CONF. OF StATE LegisLatURES (Nov. 21, 2013), http://www.ncsl.org/research/humanservices/same-sex-marriage-overview.aspx.

41. Id.

42. See id.; Same Sex Marriage Laws, NAT'L Conf. of State Legislatures (last 
only a third of the states have moved in this direction, creating roughly the mirror image of Lawrence, in which only a fourth of the states had declined to act in a favorable manner.

To be sure, there is other evidence of changing societal values. Surveys suggest that a majority of Americans now support same-sex marriage, ${ }^{43}$ thus signaling a remarkable turnaround in public opinion. ${ }^{44}$ Young people are especially supportive, and, more generally, the trend lines are strongly positive. ${ }^{45}$ In the language of Lawrence, there may be "an emerging awareness" 46 favoring a right to same-sex marriage. For the Court to rely on such reasoning here, however, would be a matter of prediction, not the accomplished fact that was evident in Lawrence. The survey evidence certainly suggests a persistent trend, but the trend is of very recent vintage, and society has had little experience with same-sex marriage, a practice that departs from centuries of tradition and that, over time, could have unanticipated consequences. ${ }^{47}$ Although it seems unlikely, the shift of societal opinion could slow in the face of experience, or opinion might even change directions once again.

Under the theory of evolving national values, there is a plausible argument that substantive due process supports a right to same-sex marriage. Yet this argument, standing alone, seems inadequate to the task. The Justices' own understanding of liberty, grounded in arguments of political morality, might very well support such a claim. Given the competing demands of federalism and the political process, however, the Justices should be reluctant to act merely on their own political-moral judgment. The shift in societal opinion is supportive, as is the recent pattern of state law recognition, but it seems premature to conclude that there is a national consensus on this issue, much less a consensus that is likely to be enduring. At least for now, substantive due process seems insufficient to support a Fourteenth Amendment right to same-sex marriage, even under a progressive theory of evolving national values. That is, substantive due process, without more, seems insufficient. But there is more.

updated Dec. 2, 2013), http://www.ncsl.org/issues-research/human-services/same-sex -marriage-laws.aspx. For an interactive map of the United States, showing changes in state law from 1995 to the present, see Same-Sex Marriage State-by-State, PEW RESEARCH Religion \& Pub. Life Project (last updated Nov. 20, 2013), http://features.pewforum.org /same-sex-marriage-state-by-state/.

43. E.g., Susan Page, Poll: Support for Gay Marriage Hits High After Ruling, USA TODAY (July 1, 2013, 10:38 PM), http://www.usatoday.com/story/news/politics/2013/07/01 /poll-supreme-court-gay-marriage-affirmative-action-voting-rights/2479541/.

44. See Nate Silver, How Opinion on Same-Sex Marriage Is Changing, and What It Means, N.Y. TIMES (Mar. 26, 2013, 10:10 AM), http://fivethirtyeight.blogs.nytimes.com /2013/03/26/how-opinion-on-same-sex-marriage-is-changing-and-what-it-means/.

45. See id. Using sophisticated modeling, Nate Silver predicts that same-sex marriage soon will command majority support throughout most of the United States. In particular, he suggests that if the issue were placed on the ballot, it would be supported by voters in thirtytwo states by 2016 and by voters in forty-four states by 2020 . Id.

46. Lawrence v. Texas, 539 U.S. 558, 572 (2003).

47. See United States v. Windsor, 133 S. Ct. 2675, 2715 (2013) (Alito, J., dissenting) ("The long-term consequences of this change are not now known and are unlikely to be ascertainable for some time to come."). 


\section{HEIGHTENED SCRUtiny EQUAL PROTECTION}

As an alternative or additional argument for extending marriage to same-sex couples, the Supreme Court, not surprisingly, might turn to the Equal Protection Clause. Beyond its obvious textual appeal, equal protection is an attractive argument because the Court's existing doctrine includes precedents that can readily be extended to the same-sex marriage context. Thus, building upon its existing doctrine, the Court could conclude, as did the Second Circuit in Windsor, that discrimination based on sexual orientation is "quasi-suspect," triggering heightened scrutiny, ${ }^{48}$ and that laws precluding gays and lesbians from marrying cannot survive this demanding review.

The central historical focus of the Equal Protection Clause was racial discrimination. ${ }^{49}$ As Professor Archibald Cox observed, however, "Once loosed, the idea of Equality is not easily cabined. ${ }^{, 50}$ Thus, the Supreme Court has treated racial discrimination as the paradigmatic "suspect classification," triggering strict judicial scrutiny and probable invalidation, ${ }^{51}$ but it has reasoned by analogy in declaring that certain other classifications also are presumptively unconstitutional. These extensions of the Equal Protection Clause reflect a reasoned extrapolation from the original meaning of the Fourteenth Amendment, but they do not depend on the original meaning in any specific sense. Instead, they rest mainly on the Justices', and society's, changing understandings of what equality demands.

In deciding whether to treat a nonracial classification as "suspect" or "quasisuspect," the Court has invoked various criteria, but, as I will explain, three have been especially influential. First, is the classifying trait, like race, an immutable personal characteristic - an accident of birth beyond a person's control or responsibility-rendering it presumptively unjust for the government to use the trait as a basis for allocating rewards or penalties? Second, is the trait, like race, broadly irrelevant to legitimate generalization, rendering discrimination on this basis not only unfair but also indefensible in a wide range of governmental settings? And third, is the disadvantaged group, like African Americans and other racial minorities, a group that lacks political power and that therefore warrants special judicial solicitude, that is, special protection from the ordinary operation of the political process?

In addressing gender discrimination, for instance, the Supreme Court, acting more than a century after the Fourteenth Amendment's ratification, moved from its

48. Windsor v. United States, 699 F.3d 169, 180-85 (2d Cir. 2012), aff'd on other grounds, 133 S. Ct. 2675 (2013).

49. Indeed, as the Supreme Court declared shortly after their ratification, all three of the post-Civil War Amendments were animated by "one pervading purpose": "the freedom of the slave race, the security and firm establishment of that freedom, and the protection of the newly-made freeman and citizen from the oppressions of those who had formerly exercised unlimited dominion over him." Slaughter-House Cases, 83 U.S. 36, 71 (1873).

50. Archibald Cox, The Supreme Court, 1965 Term-Foreword: Constitutional Adjudication and the Promotion of Human Rights, 80 HARV. L. REv. 91, 91 (1966).

51. See, e.g., Johnson v. California, 543 U.S. 499, 509 (2005) (declaring that any racial classification is "immediately suspect" and demands "strict scrutiny," which renders the classification invalid unless it is "narrowly tailored to serve a compelling state interest"). 
traditional deferential stance ${ }^{52}$ to a vigorous form of heightened scrutiny (albeit falling short of the full strict scrutiny that applies to race). In so doing, the Court made gender discrimination "quasi-suspect," for reasons best articulated in Justice Brennan's plurality opinion in Frontiero v. Richardson. ${ }^{53}$ As Brennan explained, gender is substantially similar to race under each of the three criteria that I have outlined: first, it is an "immutable characteristic determined solely by the accident of birth"; $; 4$ second, it "frequently bears no relation to ability to perform or contribute to society";55 and third, women not only suffered historically from political disadvantages ${ }^{56}$ but also (at least in 1973, when Frontiero was decided) continued to "face pervasive, although at times more subtle, discrimination," including "in the political arena." ${ }^{57}$ Accordingly, as the Court later held, genderbased classifications require an "exceedingly persuasive justification" $" 58$ and violate equal protection unless they "serve important governmental objectives and [are] substantially related to [the] achievement of those objectives." reasoning, the Court has also extended strict or heightened scrutiny to classifications based on alienage and illegitimacy. ${ }^{60}$

The Supreme Court's three-part analysis calls for judgments of fact and value, judgments that directly address political-moral questions of justice and fairness as well as the judiciary's role in redressing failures in the political process. At the same time, however, the Court's extensions of the Equal Protection Clause-for example, to protect women and illegitimate children from historically sanctioned forms of discrimination - generally have tracked the changing values of society itself. In Frontiero, for example, even as he cited the continuing political disadvantages faced by women, Justice Brennan found support for heightened scrutiny in the very fact that Congress itself, reflecting the shifting values of the day, recently had "manifested an increasing sensitivity to sex-based classifications." ${ }^{, 61}$ More broadly, speaking in a later case, Justice Marshall candidly observed that "constitutional principles of equality, like constitutional principles of liberty, property, and due process, evolve over time." ${ }^{\prime 62}$ Moreover, he continued, when "[s]hifting cultural, political, and social patterns" lead to changing patterns of

52. See, e.g., Goesaert v. Cleary, 335 U.S. 464, 466 (1948).

53. 411 U.S. 677 (1973).

54. Id. at 686 (plurality opinion).

55. Id.

56. Id. at $684-85$.

57. Id. at 686 .

58. United States v. Virginia, 518 U.S. 515, 531 (1996).

59. Craig v. Boren, 429 U.S. 190, 197 (1976).

60. See, e.g., Clark v. Jeter, 486 U.S. 456, 461 (1988) (illegitimacy); Graham v. Richardson, 403 U.S. 365, 371-72 (1971) (alienage).

61. Frontiero, 411 U.S. at 687 (plurality opinion). Brennan cited congressional antidiscrimination legislation as well as the proposed (albeit unratified) Equal Rights Amendment. Id. at 687-88.

62. City of Cleburne v. Cleburne Living Ctr., Inc., 473 U.S. 432, 466 (1985) (Marshall, J., concurring in the judgment in part and dissenting in part). 
legislation, "courts should look to the fact of such change as a source of guidance on evolving principles of equality."

Under the three-factor inquiry, the argument for extending heightened scrutiny to sexual orientation is straightforward. First, it is increasingly clear that for the vast majority of individuals, sexual orientation is immutable, not a matter of choice. ${ }^{64}$ Thus, under the first criterion, sexual orientation is a good fit, albeit not perfect. Second, as with gender, sexual orientation, in most legal settings, is an invalid basis for generalization and therefore for governmental policy making. Even if sexual orientation is relevant to certain issues, perhaps including marriage, these issues are few and far between. As a result, the second criterion is readily satisfied. And third, as the Second Circuit concluded in Windsor, the political position of gays and lesbians today is analogous to that of women at the time of Frontiero: Having endured a long history of prejudice and disadvantage, they have made considerable progress, "but they still 'face pervasive, although at times more subtle, discrimination ... in the political arena." ${ }^{65}$ As a result, it remains difficult for homosexuals "to politically protect themselves from wrongful discrimination, ${ }^{, 66}$ suggesting that the judiciary should play an active role under the Equal Protection Clause.

Simultaneously, also as in Frontiero, there is evidence of a shift in societal values that may support an evolving principle of equality that demands heightened scrutiny in this context. As with gender discrimination at the time of Frontiero, Congress recently has shown at least some "increasing sensitivity" ${ }^{\text {,67 }}$ to sexual orientation discrimination, acting in 2009 to extend special federal protection to victims of violence based on sexual orientation ${ }^{68}$ and in 2010 to repeal the discriminatory military policy known as "Don't Ask, Don't Tell." ${ }^{69}$ Many states have gone further, adopting antidiscrimination laws and policies in a variety of settings, including employment and housing. ${ }^{70}$ More generally, Americans are increasingly tolerant of homosexuality, in part because they are coming to agree that it is indeed an accident of birth. ${ }^{71}$ Thus, just as Theodore Olson argued in

63. $I d$.

64. See, e.g., Gregory M. Herek, Aaron T. Norton, Thomas J. Allen \& Charles L. Sims, Demographic, Psychological, and Social Characteristics of Self-Identified Lesbian, Gay, and Bisexual Adults in a U.S. Probability Sample, 7 SeXuality ReS. \& Soc. Pol'y 176 (2010), cited in Golinski v. U.S. Office of Pers. Mgmt., 824 F. Supp. 2d 968, 986 (N.D. Cal. 2012), appeal dismissed, Nos. 12-15388, 12-15409, 2013 U.S. App. LEXIS 15192 (9th Cir. July 23, 2013).

65. Windsor v. United States, 699 F.3d 169, 184 (2d Cir. 2012) (quoting Frontiero v. Richardson, 411 U.S. 677, 686 (1973) (plurality opinion)), aff'd on other grounds, 133 S. Ct. 2675 (2013).

66. Id.

67. Frontiero, 411 U.S. at 687 (plurality opinion).

68. See Matthew Shepard and James Byrd, Jr. Hate Crimes Prevention Act, Pub. L. No. 111-84, §§ 4701-13, 123 Stat. 2835, 2835-44 (2009).

69. See Don't Ask, Don't Tell Repeal Act of 2010, Pub. L. No. 111-321, 124 Stat. 3515 (2010).

70. See Maps of State Laws \& Policies, Hum. RTS. CAMPAign, http://www.hrc.org /resources/entry/maps-of-state-laws-policies.

71. See Jeffrey M. Jones, More Americans See Gay, Lesbian Orientation as Birth 
response to Justice Scalia's vexing question of "when," it may be that the meaning of the Equal Protection Clause changed "when we-as a culture determined that sexual orientation is a characteristic of individuals that they cannot control., ${ }^{, 72}$ Even if Americans remain divided on the particular question of same-sex marriage, their more general shift of opinion-reflected to a significant degree in legal changes at the federal and state levels - tends to support a new understanding of equal protection, an understanding that in turn may bear on the issue of marriage.

Over time, changing societal attitudes about gays and lesbians may undermine the argument that they are politically disadvantaged and therefore warrant special judicial solicitude. For now, however, it appears that homosexuals continue to face sufficient prejudice and disadvantage to satisfy the third part of the three-factor analysis. At the same time, this lingering political handicap makes their political successes, with respect to same-sex marriage and more generally, all the more remarkable and all the more indicative of evolving societal values. As with gender at the time of Frontiero, then, there is a strong argument that discrimination based on sexual orientation, including prohibitions on same-sex marriage, should be subject to heightened scrutiny under the Equal Protection Clause. Indeed, an active judicial role may be especially appropriate in vindicating a right to same-sex marriage because most of the prohibitions are embodied in state constitutional amendments, thus removing them from the ordinary process of political change. ${ }^{73}$

If the gender formulation of heightened scrutiny is applied, same-sex marriage prohibitions cannot survive in the absence of an "exceedingly persuasive justification," 74 which requires the government to demonstrate that they "serve important governmental objectives and [are] substantially related to [the] achievement of those objectives." ${ }^{75}$ By every indication, no such justification exists. As discussed below, it may very well be rational and reasonable to restrict marriage to opposite-sex couples, but that is not enough to satisfy heightened scrutiny. To be sure, there are governmental objectives that could qualify as "important"-notably, encouraging responsible procreation and sound childrearing - but these objectives are likely to falter under the "substantial relationship" requirement, because there is little evidence that same-sex marriage prohibitions substantially advance these objectives. ${ }^{76}$ Justifications along these

Factor, GALLUP POLITICS (May 16, 2013), http://www.gallup.com/poll/162569/americans -gay-lesbian-orientation-birth-factor.aspx.

72. Transcript of Oral Argument at 39, Hollingsworth v. Perry, 133 S. Ct. 2652 (2013) (No. 12-144) (quoting Theodore B. Olson). "There's no specific date in time," Olson continued. "This is an evolutionary cycle." Id.

73. In previous cases, the Supreme Court has invalidated the imposition of special political hurdles on the advancement of equality claims. See Romer v. Evans, 517 U.S. 620 (1996); Washington v. Seattle Sch. Dist. No. 1, 458 U.S. 457 (1982); Hunter v. Erickson, 393 U.S. 385 (1969).

74. United States v. Virginia, 518 U.S. 515, 531 (1996).

75. Craig v. Boren, 429 U.S. 190, 197 (1976).

76. The district court in Hollingsworth boldly concluded - in my view, mistakenlythat arguments along these lines failed even rational basis review. In any event, the court's evaluation of the evidence clearly suggests that these justifications are inadequate under heightened scrutiny. See Perry v. Schwarzenegger, 704 F. Supp. 2d 921, 999-1000 (2010), aff'd on other grounds sub nom. Perry v. Brown, 671 F.3d 1052 (9th Cir. 2012), vacated and remanded sub nom. Hollingsworth v. Perry, 133 S. Ct. 2652 (2013). 
lines, however reasonable, simply are not "exceedingly persuasive." As a result, heightened scrutiny equal protection strongly supports the invalidation of these prohibitions and therefore a Fourteenth Amendment right to same-sex marriage. ${ }^{77}$

\section{RATIONAL BASIS EQUAL PROTECTION AND ILLICIT “ANIMUS”}

As we have seen, there is a plausible argument that substantive due process supports a right to same-sex marriage, and there is a far stronger argument that equal protection supports such a right, on the ground that classifications based on sexual orientation are quasi-suspect, calling for heightened scrutiny that marriage prohibitions cannot survive. Each argument is informed by evolving societal values, and the two arguments can work in tandem. Taken together, but with equal protection doing most of the work, these arguments can readily justify a Fourteenth Amendment right to same-sex marriage.

There is a third potential basis for a right to same-sex marriage, also grounded in equal protection but not requiring a declaration that classifications based on sexual orientation are quasi-suspect. ${ }^{78}$ Instead, the Supreme Court, extending its reasoning in Windsor, could conclude that state law prohibitions on same-sex marriage are invalid even under rational basis scrutiny because they reflect an unconstitutional "animus" toward gays and lesbians, that is, "a bare ... desire to harm a politically unpopular group." Romer v. Evans, ${ }^{81}$ which also addressed discrimination based on sexual orientation. ${ }^{82}$

77. If the Supreme Court were to interpret the Fourteenth Amendment in this fashion, it would be echoing the state law rulings of three state supreme courts, including the California Supreme Court in the decision that led to Proposition 8 and later Hollingsworth. Each of these courts, applying state constitutional law, concluded that classifications based on sexual orientation warrant heightened scrutiny-indeed, in the case of California, fullfledged strict scrutiny - and that same-sex marriage prohibitions cannot survive that review. See In re Marriage Cases, 183 P.3d 384 (Cal. 2008); Kerrigan v. Comm'r of Pub. Health, 957 A.2d 407 (Conn. 2008); Varnum v. Brien, 763 N.W.2d 862 (Iowa 2009).

78. In fact, although I cannot address it in the limited space of this Essay, there is yet another equal protection argument that might be advanced, an argument grounded in the fundamental interests strand of equal protection doctrine. See Tebbe \& Widiss, supra note 23 , at $1412-49$.

79. See United States v. Windsor, 133 S. Ct. 2675, 2693 (2013) (quoting U.S. Dep't of Agric. v. Moreno, 413 U.S. 528, 534 (1973)).

80. See City of Cleburne v. Cleburne Living Ctr., Inc., 473 U.S. 432, 446-47, 450 (1985); Moreno, 413 U.S. at 534-35. As Professor Cass R. Sunstein has suggested, this strand of equal protection doctrine provides "a kind of magical trump card" that can be "used to invalidate badly motivated laws without refining a new kind of scrutiny." Cass R. Sunstein, The Supreme Court, 1995 Term-Foreword: Leaving Things Undecided, 110 HARV. L. REV. 4, 61 (1996).

81. 517 U.S. 620 (1996); see id. at 632, 634-36.

82. In Romer, the Court invalidated a Colorado constitutional amendment that had nullified and precluded state and local laws and policies protecting gays and lesbians from sexual orientation discrimination. See id. at 623-24. 
In the context of marriage, this line of reasoning might be supported in part by evolving national values, on the view that society is coming to regard opposition to same-sex marriage as not merely wrong but illegitimate - the product of antiquated and untenable prejudice and bigotry. This perspective is not implausible. As discussed earlier, there is a long history of bias against homosexuals, and this bias surely has played a role in the continuing opposition to same-sex marriage. But there are less pernicious grounds for supporting the conventional approach to marriage, and, even as societal thinking about homosexuality has evolved, it is hardly apparent that prejudice or bias is the exclusive or dominant motivation in this particular setting. As a result, the notion that evolving values support the view that marriage restrictions are animus-based is, at best, highly contentious. More generally, in my view, the Court was wrong to rely on animus reasoning in Windsor, and, in any event, it should not extend this reasoning to state laws that affirm the traditional approach to marriage.

In Windsor, the Court nullified section 3 of DOMA, a 1996 statute declaring that, regardless of state law, "marriage" under federal law was confined to opposite-sex couples. ${ }^{83}$ In an opinion by Justice Kennedy, the Court invoked various considerations, including federalism ${ }^{84}$ and hints of substantive due process. ${ }^{85}$ The Court's primary argument, however, was that Congress had acted with illicit "animus," thus violating equal protection. ${ }^{86}$ Because it declined to adopt heightened scrutiny, the Court necessarily concluded - albeit without serious discussion - that section 3 could not survive rational basis review, that is, that it did not rationally serve any legitimate governmental interest. ${ }^{87}$ Otherwise, the Court could not have concluded, as it did, that DOMA was animated by "a bare congressional desire to harm a politically unpopular group. ${ }^{.88}$

In fact, however, as noted by the Windsor dissenters, section 3 did serve interests that appear to be perfectly legitimate, and it did so in an entirely rational manner. Most obviously, it preserved, within the federal domain, an approach to marriage that had prevailed throughout history and that continues to reflect a reasoned - albeit now contested — understanding of this important institution. ${ }^{89} \mathrm{It}$

83. Defense of Marriage Act, Pub. L. No. 104-199, § 3, 110 Stat. 2419 (1996) (codified at 1 U.S.C. $\S 7$ (2006)).

84. See Windsor, 133 S. Ct. at 2689-93 (emphasizing that the states, not the federal government, have the primary authority to define and regulate marriage).

85. See id. at 2695 (declaring that DOMA denies "the liberty protected by the Due Process Clause of the Fifth Amendment" and is an unconstitutional "deprivation of the liberty of the person"); see also id. at 2692 (citing Lawrence v. Texas, 539 U.S. 558, 567 (2003), a substantive due process case, for the proposition that homosexual intimacy "can form 'but one element in a personal bond that is more enduring"').

86. See id. at 2693, 2695 (citing Boling v. Sharpe, 347 U.S. 497 (1954), and noting that the Fifth Amendment's Due Process Clause includes an equal protection component).

87. Cf. id. at 2696 (stating that "no legitimate purpose overcomes the purpose and effect to disparage and to injure" same-sex married couples).

88. Id. at 2693 (quoting U.S. Dep't of Agric. v. Moreno, 413 U.S. 528, 534 (1973)).

89. See id. at 2718-19 (Alito, J., dissenting); see also Michael J. SANDEL, Justice: WhAT's THE Right ThiNG TO Do? 258-59 (2009) (explaining that there are competing conceptions of "the purpose, or telos, of marriage as a social institution," with the traditional view focusing on procreation and the argument for same-sex marriage emphasizing loving 
likewise advanced interests in legal stability and uniformity, ${ }^{90}$ and it avoided difficult choice-of-law questions, questions that now will arise precisely because this provision has been nullified. ${ }^{91}$ In reality, the Court could not invalidate section 3 under ordinary rational basis principles. Rather, it seems clear that the Court applied a version of heightened scrutiny. But it did so sub silencio, and therefore without a stated justification.

As I have explained, there is a strong argument that laws discriminating against gays and lesbians, including section 3 of DOMA, should indeed be subject to heightened scrutiny. But there is little to be said for judicial obfuscation. Justice Marshall's observation concerning an earlier "animus" ruling is equally fitting here: "[I]t is important to articulate, as the Court does not, the facts and principles that justify subjecting [a law] to the searching review - the heightened scrutinythat actually leads to its invalidation. ${ }^{92}$ What is more, as Chief Justice Roberts observed in Windsor, a finding of legislative "animus" is insulting and disrespectful, "tar[ring] the political branches with the brush of bigotry." Windsor, the Court accused Congress of acting (by overwhelming congressional majorities, no less) ${ }^{94}$ merely — or at least primarily—purposefully to "injure,",95 "disapprov[e],"96 "stigma[tize]," "demean,",98 and "degrade" "99 same-sex married couples and to "humiliate[]" their children. ${ }^{100}$ This is an especially disturbing charge when, as here, the judicial insult is gratuitous, because the Court could readily have reached the same result in another, far more persuasive manner: by candidly adopting heightened scrutiny and invalidating section 3 on that basis.

When the question turns from DOMA to state laws, moreover, there are additional reasons for avoiding animus-based reasoning. In the first place, the statelaw context eliminates the federalism concern that was present in Windsor and that the Court directly linked to its animus rationale. Declaring that "[d]iscriminations

commitment).

90. See Windsor, 133 S. Ct. at 2696 (Roberts, C.J., dissenting); id. at 2708 (Scalia, J., dissenting).

91. Id. at 2708 (Scalia, J., dissenting) (citing William Baude, Beyond DOMA: Choice of State Law in Federal Statutes, 64 Stan. L. Rev. 1371 (2012)); see also Deborah A. Widiss, Leveling Up After DOMA, 89 IND. L.J. 43 (2014) (arguing that the federal government should address these complexities by extending uniform federal rights to samesex couples across the country).

92. City of Cleburne v. Cleburne Living Ctr., Inc., 473 U.S. 432, 456 (1985) (Marshall, J., concurring in the judgment in part and dissenting in part); see id. at 459-60 (explaining that ill-defined and poorly justified precedents leave lower courts uninformed and the Supreme Court unaccountable).

93. Windsor, 133 S. Ct. at 2696 (Roberts, C.J., dissenting).

94. See id.

95. Id. at 2693 (majority opinion).

96. Id.

97. Id.

98. Id. at 2695.

99. Id.

100. $I d$. at 2694. In an earlier decision protecting gay rights, also authored by Justice Kennedy, the Court was more charitable. See Lawrence v. Texas, 539 U.S. 558, 571 (2003) (describing opposition to homosexual conduct as a product not of animus or bigotry but rather of "profound and deep convictions accepted as ethical and moral principles"). 
of an unusual character" are more likely to reflect "an improper animus or purpose," 101 the Court concluded that "DOMA's unusual deviation from the usual tradition of recognizing and accepting state definitions of marriage . . . is strong evidence of a law having the purpose and effect of disapproval." 102 According to the Court, then, there were two competing traditions in Windsor: the tradition of opposite-sex marriage, recognized "throughout the history of civilization," 103 but also the tradition of treating marriage questions "as being within the authority and realm of the separate States." 104 State law prohibitions on same-sex marriage, by contrast, simultaneously honor both traditions, making them immune from the charge that they deviate from tradition and are therefore suggestive of illicit animus. ${ }^{105}$ Nor, with rare exception, do these prohibitions take away preexisting state law rights, a factor cited by the Ninth Circuit in Hollingsworth to support its finding of improper animus in the adoption of California's Proposition 8. ${ }^{106}$ More generally, like President Obama before his recent change of heart, those who oppose same-sex marriage may be wrong, but it would be equally wrong to "tar [them] with the brush of bigotry." 107

In addition, the recognition of same-sex marriage as a Fourteenth Amendment right will raise a host of religious liberty questions. In Hollingsworth and Windsor, the Supreme Court turned a deaf ear to these questions, ignoring an amicus brief from prominent religious liberty scholars (Douglas Laycock, Marc D. Stern, and Thomas C. Berg) on behalf of the American Jewish Committee. ${ }^{108}$ The brief urged the Court, as it moves toward the recognition of same-sex marriage, to ensure not only the liberty of same-sex couples - which the brief fully supports - but also the liberty of religious objectors. ${ }^{109}$ Needless to say, if the Court were to recognize a right to same-sex marriage by characterizing opponents as animus-driven, that

101. Windsor, 133 S. Ct. at 2693 (quoting Romer v. Evans, 517 U.S. 620, 633 (1996)).

102. Id

103. Id. at 2689 .

104. Id. at 2690 .

105. It may be that states deviate from a tradition of horizontal federalism-creating the potential for a Windsor-like argument-when they refuse to recognize the marriages of migrating same-sex couples who were lawfully married in another state. See Steve Sanders, Next on the Agenda for Marriage Equality Litigators . . ., SCOTUSBLOG (June 26, 2013, 5:40 PM), http://www.scotusblog.com/2013/06/next-on-the-agenda-for-marriage-equalitylitigators/.

106. See Perry v. Brown, 671 F.3d 1052, 1079-81 (9th Cir. 2012), vacated and remanded sub nom. Hollingsworth v. Perry, 133 S. Ct. 2652 (2013).

107. Windsor, 133 S. Ct. at 2696 (Roberts, C.J., dissenting).

108. Brief Amicus Curiae of the American Jewish Committee in Support of the Individual Respondents on the Merits, Hollingsworth v. Perry, 133 S. Ct. 2652 (2013) (No. 12-144), United States v. Windsor, 133 S. Ct. 2675 (2013) (No. 12-307).

109. See id.; cf. Brief Amicus Curiae of the Becket Fund for Religious Liberty in Support of Hollingsworth and the Bipartisan Legal Advisory Group Addressing the Merits, Hollingsworth v. Perry, 133 S. Ct. 2652 (2013) (No. 12-144), United States v. Windsor, 133 S. Ct. 2675 (2013) (No. 12-307) (citing religious liberty concerns in urging judicial restraint in the consideration of same-sex marriage claims); see generally SAME-SEX MARRIAGE AND Religious LiberTy (Douglas Laycock, Anthony R. Picarello, Jr. \& Robin Fretwell Wilson eds., 2008) (collection of essays highlighting religious liberty issues). 
reasoning would hardly support a sensitive accommodation of these important competing liberties. ${ }^{110}$

\section{CONCLUSION}

Returning to Justice Scalia's question about the Fourteenth Amendment's meaning over time, I would propose the following response: A constitutional right to same-sex marriage will emerge, and properly so, when the Supreme Court determines that justice so requires and when that determination is sufficiently supported by evolving national values that the Court's recognition of this right "will-in time, but in a rather immediate foreseeable future-gain general assent." ${ }^{111}$ In my judgment, we are fast approaching that juncture. ${ }^{112}$ The Court could rely on "animus" reasoning to reach this result, and, if Scalia is correct, it is likely to do so. ${ }^{113}$ But that line of analysis was seriously flawed in Windsor, and it would be especially misguided, or at least imprudent, for the Justices to extend it to the state-law context. As an alternative rationale, substantive due process would provide plausible support for a right to same-sex marriage, but only to a limited degree. By every indication, the strongest, most candid, and most judicious rationale would rest on equal protection, with the Court concluding that classifications based on sexual orientation are quasi-suspect, triggering heightened scrutiny that marriage prohibitions cannot survive.

110. Cf. Richard W. Garnett, Worth Worrying About?: Same-Sex Marriage and Religious Freedom, CommonweAL (Aug. 5, 2013, 3:35 PM), http://www.common wealmagazine.org/worth-worrying-about (arguing that the Supreme Court's reasoning in Windsor, characterizing DOMA supporters "as backward and bigoted, unworthy of respect... is not likely to generate compromise or accommodation and so . . . poses a serious challenge to religious freedom").

111. BICKEL, supra note 14 , at 239.

112. Even the opponents of same-sex marriage increasingly believe that its recognition is inevitable, a position that does not suggest enduring resistance. In Gay Marriage Debate, Both Supporters and Opponents See Legal Recognition as 'Inevitable', PEW RESEARCH CTR. FOR THE PEOPLe \& THE PRESS (June 6, 2013), http://www.people-press.org/2013/06/06/in -gay-marriage-debate-both-supporters-and-opponents-see-legal-recognition-as-inevitable/.

113. See Windsor, 133 S. Ct. at 2709-10 (Scalia, J., dissenting). 